\title{
Effects of forest healing program activities using natural environments on the respect for life and prosocial behavior of 5-year-old child
}

\author{
Cheoul-Soon Jang ${ }^{1}$, Chang-Seob Shin ${ }^{2}$, and Hong-Gyoo Kim \\ ${ }^{1}$ Graduate Department of Forest Therapy, Chungbuk National University, Cheongju 28644, Korea \\ ${ }^{2}$ Department of Forestry, Chungbuk National University, Cheongju 28644, Korea
}

\begin{abstract}
The purpose of this study was to investigate the effect of forest healing program activities using natural environments on life recognition and prosocial behavior of child. Kindergarten children in Cheongju City were divided into two test groups and a control group. Test Group A participated in the forest healing program at the Infant Forest Experiences Center, while Test Group B had forest healing program activities in the classrooms of early childhood education institutions. Control group did not carry out the forest healing program but carried out the program by the Nuri Curriculum. The forest healing program was conducted once a week for a total of 12 sessions, each session lasting one hour. The forest healing program is based on physical and chemical sensory factors through the five senses. The effect of the forest healing program, and the data were analyzed by one way ANOVA and covariance analysis (ANCOVA). According to the result, the children of Test group A showed greater improvements in all sub-factors of respect for life (perspective on respect for life, knowledge of respect for life, and cooperative behavior with respect for life) than Test group B or Control group. Test group A also showed an increasing trend in all sub-factors of prosocial behavior (ability to regulate personal emotions, ability to build interpersonal relationships, and ability to adapt to kindergarten). The forest healing program using natural environments showed significant effects on the respect for life and prosocial behavior for 5-year old children.
\end{abstract}

Keywords: awareness of forest, forest healing, forest walks

\section{Introduction}

Humans are destined to harmonize and coexist with nature and thus need ecological education about nature in order to enjoy a sound and healthy life. Young children perceive the value of coexisting life by encountering and experiencing nature, and realize that each entity of the ecosystem has its own value as a being, thereby perceiving the need to maintain a harmonious relationship of interdependent and cyclical life. Thus, early childhood is the right time to receive ecological education (Kwon, 2011).

For a long time, traditional early childhood education in Korea has perceived educational experience in nature as highly valuable and important. Experiencing and perceiving the relationship between nature and humans in early childhood not 
only satisfies intellectual curiosity but also develops all kinds of wisdom to live in coexistence.

Early childhood education by Comenius, Pestalozzi, and Froebel et al. was carried out as 'nature learning' focusing on play based on sensory experiences (Lee, 2008). Lim (2007) emphasized nature-friendly education for children to grow up socially healthy, and claimed that this enables them to become close with animals and plants in nature and get along with children of various ages, building relaxed interpersonal relationships (Kim, 2013). Thus, nature is the most excellent space and playground for a child to grow up as a child (Jang, 2017).

The Nuri Curriculum of early childhood education institutions in Korea by age requires at least one hour a day of outdoor play. According to the nature exploration field of the Nuri Curriculum for 5-year-old children, the objective of education is to creatively think and explore based on respect for nature since early childhood in order to live a harmonious life with nature. In the social relations field, the objective is to respect oneself and develop the ability and attitude to live with others (Ministry of Education and Science Technology, 2015). By doing so, young children can relieve stress, experience and observe the natural environment, build pro-social relationships with peers, and develop the perception on respect for life toward nature. Young children are very curious about nature and enjoy exploring it due to their developmental characteristics. Thus, the opportunity to frequently experience direct interaction with nature is absolutely necessary for the younger ages (Wilson, 1995; Hong, 2003).

Young children can develop a great deal of intellectual curiosity through activities using natural objects as they see, learn and feel through experiences in nature. Moreover, forests are highly beneficial for children's brain development due to cleaner air and oxygen (Shin, 2007). Forests have various materials that stimulate young children's sensitivity and curiosity, thereby helping them develop linguistic and mathematical skills, enrich sensitivity, and have various and big interest and discoveries about objects (Seo, 2008; Oh, 2010). As such, nature helps young children naturally develop their potential abilities. Exploring nature is an important experience for the five senses of young children, as they can directly observe objects, listen to the sounds in the forest, smell things, taste fruits, and touch all kinds of things (Jang and Koo, 2017).

Early childhood is the time when education about respect for life begins. Respect for life is being aware that all living things mutually affect one another and valuing them, and being interested in all living things such as humans, animals and plants, caring for them and respecting them preciously (Choi, 2016). The forest is the place that enlightens the hidden sensitivity of young children and teaches them to unconditionally love all living and non-living things in addition to learning the value of life (Nam, 2004). The activity of exploring nature through forest walking primarily teaches young children to feel deep interest and love for nature, and have respect for life as they see living insects, birds, plants and animals. The right perception about life enables young children to value living things in their minds and feel respect for life.

Young children show various prosocial behaviors as they grow older. Even before they are one year old, they respond with hand gestures or motions by interacting with their mothers, and tend to share interesting things. After they turn one, they begin to express affection by sharing their toys with familiar people such as mother or father, help out the adults, and show various prosocial behaviors such as comforting others (Hay, 1984). It is necessary to expand the concept of prosocial behavior to be interested in prosocial behavior that is suitable for young children (Moore, 2000).

As such, early childhood is the time in which children establish the value system to respect and love living things, and it is also an important time for them to form a nature-friendly attitude (Oh, 2017). This is mainly because early childhood is the transitional period in which they solidify the grounds of social knowledge and divert attention to the outside world from their homes, thereby learning about others from the value-centered self (Yu, 2018). In other words, they perceive their relationships with others in the society and learn the process of social adjustment through which they live in cooperation with others (Choi, 2013). Young children learn nature-friendly attitudes and respect for life through ecological experience activities, and establish the positive mindset and healthy value system to realize and protect the value of life (Baeg, 2014). 
A forest is where young children can most naturally experience nature by detecting and perceiving the diversity of life. Moreover, a forest gets rid of young children's fear about nature and provides them with infinite imagination and curiosity. Therefore, there are many studies that verified the effects of activities using natural objects in forests (Hong, 2003; Gwon, 2003; Aan, 2007). However, to verify the effects of forests, it is necessary to compare the differences between carrying out activities in the forest and in the classroom.

Thus, this study will examine the differences in young children's perception on respect for life and prosocial behavior between carrying out forest healing program activities using natural objects in the forest and the classroom, and also the comparative group that did not participate in the program, according to the social trend emphasizing nature.

\section{Methods}

\section{Subjects}

The subjects are total 60 young children attending an early childhood education institute located in OO-dong, Sangdang-gu in Cheongju, divided into 40 children in the Test group (A: 20, B: 20) that participated in the pretest-posttest survey and 20 in the control group by class. Test group A participated in forest healing program activities at an early childhood forest experience center located in OO-dong, Cheongju. Test group B participated in the same forest healing program activities as Test group A in a classroom of the educational institution. The control group participated in the Nuri Curriculum program at the educational institution without participating in the forest healing program. The age distribution of the subjects is as shown in Table 1.

\section{Implementation of the program}

\section{Contents of the program for the Control group}

First, the control group carried out the program by the Nuri Curriculum at the educational institution by allowing young children to choose the activities they want and carry them out during the free choice activity session. The Nuri Curriculum refers to the standard curriculum implemented by the government since 2012 to guarantee equal opportunities of education and care for children aged 3-5 attending kindergartens and daycare centers (Ministry of Education and Science Technology, 2012). The monthly programs are 'Spring, fauna and flora' for April,'Me and my family' for May, and 'Hometown' for June (Table 2).

\section{Main contents of the program applied to Test groups A and B}

The forest healing program is designed by us based on previous studies, selected after verifying the reliability and validity of the program with experts ( 1 head of the early childhood educational institution, 2 preschool homeroom

Table 1. Basic characteristics of the study subjects

\begin{tabular}{|c|c|c|c|c|}
\hline \multirow{2}{*}{ Group } & \multirow{2}{*}{$\mathrm{n}$} & \multicolumn{2}{|c|}{ Gender } & \multirow{2}{*}{ Average age in months } \\
\hline & & Male & Female & \\
\hline Test group A & 20 & 11 & 9 & 63.14 \\
\hline Test group B & 20 & 9 & 11 & 62.15 \\
\hline Control group & 20 & 10 & 10 & 61.89 \\
\hline Total & 60 & 30 & 30 & 62.39 \\
\hline
\end{tabular}


Table 2. Contents of the choice activity program in the classroom for Control group

\begin{tabular}{|c|c|c|c|c|}
\hline \multicolumn{2}{|l|}{ Division } & April & May & June \\
\hline & Subject & Spring, fauna and flora & Me and my family & Hometown \\
\hline \multirow{7}{*}{$\begin{array}{c}\text { Free } \\
\text { choice } \\
\text { activity }\end{array}$} & Block area & Tree & Decorate me and my family & Create an alley with blocks \\
\hline & Role play area & Spring cleanup day & Security guard house & Role play - at the restaurant \\
\hline & Language area & Draw a spring garden & Name parts of the body & $\begin{array}{l}\text { Decorate your neighborhood } \\
\text { with clay }\end{array}$ \\
\hline & Mathematics and science & Let's put it in order of growing & Odd or even & Memory game \\
\hline & Science field & $\begin{array}{l}\text { Observe spring flowers and } \\
\text { leaves with a magnifying glass }\end{array}$ & Look at my face in the mirror & $\begin{array}{l}\text { Mirror play - discover } \\
\text { symmetry }\end{array}$ \\
\hline & Molding area & Cotton ball experiment & Decorate your own clothes & Decalcomania \\
\hline & Music and rhythm zone & Whisper of spring & Music for pieces of wood & Singing together \\
\hline
\end{tabular}

Table 3. Main contents of the forest healing program by session for Test groups $A$ and $B$

\begin{tabular}{|c|c|c|c|c|c|}
\hline Session & Program contents & Purpose & $\begin{array}{l}\text { Field of five senses } \\
\text { experience }\end{array}$ & $\begin{array}{l}\text { Forest healing } \\
\text { factor }\end{array}$ & Detail factor \\
\hline 1 & Greeting the woods & $\begin{array}{l}\text { Walk through the forest and become } \\
\text { a friend of forest }\end{array}$ & All senses & Sensory factor & Walking \\
\hline 2 & $\begin{array}{l}\text { Finding something } \\
\text { precious in the woods }\end{array}$ & $\begin{array}{l}\text { I see what I can see in the forest and } \\
\text { look for a natural object that } \\
\text { resembles me }\end{array}$ & All senses & Sensory factor & Walking \\
\hline 3 & View of forest landscape & $\begin{array}{l}\text { Being surrounded by trees make me } \\
\text { happier }\end{array}$ & Visual sense & Chemical factor & $\begin{array}{l}\text { Landscape of the } \\
\text { forest }\end{array}$ \\
\hline 4 & A soft woody scent & $\begin{array}{l}\text { Touch the grass and trees in the } \\
\text { forest and feel the various scents }\end{array}$ & Olfactory sense & Chemical factor & Fragrance of forest \\
\hline 5 & $\begin{array}{l}\text { I am a painter } \\
\text { in the woods }\end{array}$ & $\begin{array}{c}\text { Taste a variety of fruits Draw a } \\
\text { picture }\end{array}$ & Taste sense & Sensory factor & Fruit \\
\hline 6 & Wind, oh cool! & Feel the wind in the forest & Touch sense & Physical factor & Wind in the forest \\
\hline 7 & $\begin{array}{l}\text { What are you talking } \\
\text { about? }\end{array}$ & $\begin{array}{c}\text { Listen to the various sounds of the } \\
\text { forest }\end{array}$ & Auditory sense & Sensory factor & Sound \\
\hline 8 & I want to be a tree & $\begin{array}{l}\text { Let the forests change according to } \\
\text { the season }\end{array}$ & Olfactory sense & $\begin{array}{c}\text { Social factor } \\
\text { Psychological factor }\end{array}$ & Leaf \\
\hline 9 & The skin of the tree & $\begin{array}{l}\text { Observe various bark and do bark } \\
\text { rubbings with paper }\end{array}$ & Touch sense & Physical factor & Bark \\
\hline 10 & Forest craft Class & $\begin{array}{l}\text { Make mobiles using full of raw } \\
\text { materials }\end{array}$ & Touch sense & Physical factor & Twig \\
\hline 11 & $\begin{array}{l}\text { Relaxing, lying down } \\
\text { in forest }\end{array}$ & $\begin{array}{l}\text { Lie down on the ground looking up } \\
\text { at the sky, and enjoy the five senses }\end{array}$ & All senses & Sensory factor & Forest meditation \\
\hline
\end{tabular}

teachers, 2 forest kindergarten teachers, and 2 forest healing consultants). Detailed activities are as shown in Table 3.

Test group A carried out forest healing program activities at the early childhood forest experience center located in OO-dong, Cheongju. This center was built by the Korea Forest Service and has a trail, pavilion, sand playground, pond to observe aquatic plants, nature facilities, learning spaces and rest areas in different themes, and a place to take shelter from rain so that children can participate safely in the activities at the forest. The main species of trees at the center include Pinus densiflora, Larix leptolepis, Robinia pseudoacacia, Abies koreana, Liriodendron tulipifera, Acer palmatum, 
Magnolia obovata, Hibiscus syriacus, Euonymus alatus, etc. There is a pond to observe aquatic plants, which is rich in forest healing factors such as physical and chemical factors. The forest also has a trail with a gentle slope that is convenient for children to walk, which lowers the risk of negligent accidents and provides excellent conditions for their activities. The activities were freely carried out after lunch during the free choice play hours, moving to the forest starting from 1 p.m.

Test group B carried out the same program as A, not in the forest but in the classroom.

\section{Execution process of the forest healing program}

This study was conducted once a week for 12 weeks from April 2 to June 22, 2018. The Test groups participated in forest healing program activities after their morning routine. To prepare for negligent accidents and enable children to smoothly participate in activities without conflicts during the program, 2 homeroom teachers, 2 forest kindergarten teachers and 2 forest healing consultants accompanied the researchers and helped out in the middle so that no children are left behind. Before entering the forest, children are informed of precautions and they do some warm-up exercises to prevent any strain considering their physical conditions. After the preparations, they are to naturally walk along the forest trail with the researchers, homeroom teachers, forest kindergarten teachers and forest healing consultants. They are to naturally stroll along as they talk about the things they felt and saw. The forest healing program activities were carried out as they moved only along the trail in order to prevent negligent accidents.

Table 4 shows the detailed process of forest healing program activities.

\section{Measurement tools}

\section{Measurement tool for perception on respect for life}

The tool used to measure the effects of the forest healing program on preschool children's perception on respect for life was the questionnaire used by Kim (2002) and revised by Lee (2005) to meet the level of preschool children. The questionnaire about respect for life provided in this study consists of perspective on respect for life, knowledge of respect for life, and cooperative behavior with respect for life, with 8 items in each category adding up to total 24 items.

The items are rated on a 3-point Likert scale, with 'Good, Yes' marked as O, 'Don't know, Average' as $\triangle$, and 'Bad, No' as X. The reliability testing results of the 24 items turned out to be Cronbach's $\alpha$ (reliability coefficient) 79 in Lee's study, but it was .80 in this study. Table 5 shows the specific details and reliability coefficients for preschool children's respect for life.

Table 4. Sequence of forest healing program

\begin{tabular}{|c|c|c|}
\hline Stage & Time (minute) & Content \\
\hline \multirow{2}{*}{ Preparation } & 5 & Give the precautions to children before entering the forest \\
\hline & 5 & Simple warm up and stretching to avoid injury \\
\hline $\begin{array}{l}\text { Performing the } \\
\text { program }\end{array}$ & 40 & $\begin{array}{l}\text { - Look at the forest landscape } \\
\text { - Walk through the forest, let nature enter your body through all five senses, and talk freely about what } \\
\text { you can see in the forest } \\
\text { - The teacher helps the child to observe the forest freely }\end{array}$ \\
\hline Wrap up & 10 & $\begin{array}{l}\text { - Talk about what you saw in the forest } \\
\text { - Clean up the surroundings if necessary }\end{array}$ \\
\hline
\end{tabular}


Table 5. Reliability of item composition and measurement tools by sub-factors of children's respect for life

\begin{tabular}{lcccc}
\hline \multicolumn{1}{c}{ Constituent factor } & Picture check number & Number of items & \multicolumn{2}{c}{ Cronbach' $\alpha$} \\
\cline { 3 - 6 } & & & H.O. Lee (2005) & This study \\
\hline Perspective on respect for life & $1,2,3,4,5,6,7,8$ & 8 & .72 & .76 \\
Knowledge of respect for life & $9,10,11,12,13,14,15,16$ & 8 & .76 & .87 \\
Cooperative behavior with respect for life & $17,18,19,20,21,22,23,24$ & 8 & .79 & .88 \\
Total & 24 & 24 & .80 \\
\hline
\end{tabular}

Table 6. Reliability of item composition and measurement tools by sub-factors of children's prosocial behavior

\begin{tabular}{lcccc}
\hline \multirow{2}{*}{ Constituent factor } & Picture check number & Number of items & \multicolumn{2}{c}{ Cronbach' $\alpha$} \\
\cline { 3 - 5 } & & & E.S. Kim (2013) & This study \\
\hline Ability to regulate personal emotions & $1,2,3,4,5$ & 5 & .72 & .73 \\
Ability to build interpersonal relationships & $6,7,8,9,10$ & 5 & .69 & .83 \\
Ability to adapt to kindergarten & $11,12,13,14,15$ & 5 & .75 & .82 \\
Total & 15 & 15 & .77 \\
\hline
\end{tabular}

\section{Testing tool for preschool children's prosocial behavior}

The tool used to examine preschool children's prosocial behavior is the Skill Situations Measure developed by McGinnis \& Goldstein (1990. as cited in E.S. Kim, 2013), adapted, excerpted and revised by Lee et al. (1993. as cited in E.S. Kim, 2013), and used by E.S. Kim (2013). To promote understanding of preschool children, each item consists of pictures describing each situation and picture recognition tasks using questions about the images.

The test was conducted during free choice play hours in the form of one-on-one individual interviews between tester and child. For the test, the tester builds sufficient affinity with the child, and then tells the child about the test: "Now I'm going to show you picture cards and tell you a story. Can you listen carefully and tell me what you think?" The child is presented with picture materials and stories about 15 items, after which his or her verbal response is recorded according to each story. If the child does not show any response after the teacher asks the question, the teacher is not to urge the child to answer, but instead mark as 'no response' if the child does not respond after 30 seconds.

Only prosocial responses are scored 1 point, and others are all scored 0 point. The scores of each category are calculated according to the children's responses, and added up to come up with the total score. The range of scores is 0-15 points, adding up to total 15 points with 5 for each category. Thus, the total score of the test result ranges from minimum 0 to maximum 15, with the total score indicating the score of prosocial behavior. The reliability of the research tool turned out to be Cronbach's $\alpha$ (reliability coefficient) .75 in Kim's study, but it was .77 in this study. Table 6 shows the specific details and reliability coefficients for preschool children's prosocial behavior test.

\section{Data analysis}

To determine the effects of the forest healing program on preschool children's awareness of respect for life and prosocial behavior, we used One Way ANOVA to verify the homogeneity of the subjects, and ANCOVA to analyze the awareness of respect for life and prosocial behavior. The collected data were analyzed using SPSS WINDOW 18.0 program, and the significance level was $p<.05$. 


\section{Results and Discussion}

This study determines the effects of after-school forest healing program activities using natural objects on preschool children's awareness of respect for life and prosocial behavior. The results are as follows.

\section{Results of homogeneity testing between Test groups (A, B) and Control group}

As a result of conducting homogeneity testing by age between the Test groups and Control group before applying forest healing program activities, the sub-factors of awareness of respect for life (perspective on respect for life, knowledge of respect for life, and cooperative behavior with respect for life) and sub-factors of prosocial behavior (ability to regulate personal emotions, ability to build interpersonal relationships, and ability to adapt to kindergarten) were proved as statistically homogeneous groups as presented in Table $7(p>.05)$.

\section{Verification of effects of the forest healing program on preschool children's awareness of respect for life}

\section{Testing of pretest-posttest effects}

Table 8 shows the pretest-posttest mean and standard deviation of awareness of respect for life for each group.

As shown in pretest-posttest changes of Table 8 , children that were first unfamiliar with the forest environment began to cooperate with their teachers and peers and became more familiar with the forest as the sessions went on through various activities of the forest healing program using natural objects. The mean of Test group A increased greatly from 2.251 to 2.618, but the mean of Test group B and control group increased slightly from 2.203 to 2.351, and 2.143 to 2.255 , respectively. The mean generally increased in the subfactors such as perspective on respect for life, knowledge of respect for life, and cooperative behavior with respect for life.

There is unlimited area of play and activities because everything can be entertaining in nature. However, it was discovered that the children tended to focus on certain things while they freely participated in the activities.

\section{Pretest-posttest ANCOVA results of preschool children's awareness of respect for life according to the implementation} of the forest healing program

To verify the effects of the forest healing program developed in this study on preschool children's awareness of respect for life and prosocial behavior, we conducted ANCOVA that verifies the differences in posttest scores for each group by using the pretest scores of the Test and control groups as covariance. Table 9 shows the results of pretest-posttest ANCOVA.

Table 7. Results of homogeneity test between Test groups and Control group

\begin{tabular}{|c|c|c|c|c|c|}
\hline Factor & Sub-factor & Levene statistic & df1 & df 2 & $p$ \\
\hline \multirow{4}{*}{$\begin{array}{l}\text { Recognition of } \\
\text { respect for life }\end{array}$} & Perspective on respect for life & .354 & 2 & 57 & .704 \\
\hline & Knowledge of respect for life & .561 & 2 & 57 & .574 \\
\hline & Cooperative behavior with respect for life & .361 & 2 & 57 & 699 \\
\hline & Total & .427 & 2 & 57 & 654 \\
\hline \multirow{4}{*}{$\begin{array}{l}\text { Prosocial } \\
\text { behavior }\end{array}$} & Ability to regulate personal emotions & .602 & 2 & 57 & .551 \\
\hline & Ability to build interpersonal relationships & .332 & 2 & 57 & .719 \\
\hline & Ability to adapt to kindergarten & .294 & 2 & 57 & .747 \\
\hline & Total & .158 & 2 & 57 & .854 \\
\hline
\end{tabular}


Table 8. Pre- and post-test effects on children's respect for life

\begin{tabular}{|c|c|c|c|c|c|}
\hline \multirow{2}{*}{ Factor } & \multirow{2}{*}{ Sub-factor } & \multirow{2}{*}{ Group } & \multirow{2}{*}{$\mathrm{n}$} & Before & After \\
\hline & & & & \multicolumn{2}{|c|}{$\mathrm{M} \pm \mathrm{SD}$} \\
\hline \multirow{12}{*}{$\begin{array}{l}\text { Recognition of } \\
\text { respect for life }\end{array}$} & \multirow{3}{*}{ Perspective on respect for life } & Test group A & 20 & $2.250 \pm .225$ & $2.715 \pm .115$ \\
\hline & & Test group B & 20 & $2.160 \pm .211$ & $2.347 \pm .365$ \\
\hline & & Control group & 20 & $2.131 \pm .192$ & $2.244 \pm .255$ \\
\hline & \multirow{3}{*}{ Knowledge of respect for life } & Test group A & 20 & $2.237 \pm .246$ & $2.554 \pm .140$ \\
\hline & & Test group B & 20 & $2.200 \pm .211$ & $2.272 \pm .164$ \\
\hline & & Control group & 20 & $2.150 \pm .209$ & $2.272 \pm .196$ \\
\hline & \multirow{3}{*}{ Cooperative behavior with respect for life } & Test group A & 20 & $2.268 \pm .254$ & $2.587 \pm .167$ \\
\hline & & Test group B & 20 & $2.025 \pm .213$ & $2.435 \pm .131$ \\
\hline & & Control group & 20 & $2.250 \pm .209$ & $2.435 \pm .125$ \\
\hline & \multirow{3}{*}{ Total } & Test group A & 20 & $2.251 \pm .178$ & $2.618 \pm .108$ \\
\hline & & Test group B & 20 & $2.203 \pm .229$ & $2.351 \pm .107$ \\
\hline & & Control group & 20 & $2.143 \pm .207$ & $2.255 \pm .206$ \\
\hline
\end{tabular}

Table 9. Pre- and post-categorical covariance analysis of children's respect for life perceived by forest healing program

\begin{tabular}{|c|c|c|c|c|c|c|c|}
\hline Factor & Sub-factor & Variable Source & SS & df & MS & $\mathrm{F}$ & $p$ \\
\hline \multirow{16}{*}{$\begin{array}{l}\text { Recognition of } \\
\text { respect for life }\end{array}$} & \multirow{4}{*}{$\begin{array}{l}\text { Perspective on respect } \\
\text { for life }\end{array}$} & Covariance & .007 & 1 & .007 & & \\
\hline & & Intergroup & .880 & 2 & .440 & 6.136 & $.004 * *$ \\
\hline & & Error & 4.024 & 56 & .072 & & \\
\hline & & Total & 387.837 & 60 & & & \\
\hline & \multirow{4}{*}{$\begin{array}{l}\text { Knowledge of respect } \\
\text { for life }\end{array}$} & Covariance & .001 & 1 & .001 & .017 & \\
\hline & & Intergroup & .969 & 2 & .484 & 16.763 & $.000 * *$ \\
\hline & & Error & 1.618 & 56 & .029 & & \\
\hline & & Total & 338.735 & 60 & & & \\
\hline & \multirow{4}{*}{$\begin{array}{l}\text { Cooperative behavior } \\
\text { with respect for life }\end{array}$} & Covariance & .271 & 1 & .271 & & \\
\hline & & Intergroup & .219 & 2 & .110 & 6.897 & $.002 * *$ \\
\hline & & Error & .894 & 56 & .016 & & \\
\hline & & Total & 368.853 & 60 & & & \\
\hline & \multirow{4}{*}{ Total } & Covariance & .527 & 1 & .527 & 40.599 & \\
\hline & & Intergroup & 1.319 & 2 & .665 & 51.161 & $.000 * *$ \\
\hline & & Error & .727 & 56 & .013 & & \\
\hline & & Total & 353.125 & 60 & & & \\
\hline
\end{tabular}

${ }^{*} p<.05,{ }^{* *} p<.01$

The pretest-posttest between-group ANCOVA results of awareness of respect for life showed that the subfactors such as perspective on respect for life, knowledge of respect for life, and cooperative behavior with respect for life were statistically significant.

Accordingly, five senses activities using natural objects such as insects, birds, fish, trees, flowers, fruits, rocks, stones, moss and branches in the diverse natural environments of the forest affected the children's self-efficacy, creativity and awareness of respect for life (Jang, 2017). In particular, nature had positive effects on preschool children's awareness of 
respect for life as it is learned more extensively and deeply (Oh, 2017). The results are also consistent with previous studies proving significant effects in the subfactors of awareness of respect for life, such as effects of nature meditation with forest play on preschool children's awareness of respect for life and self-regulation (Lee, 2015), effects of personality education based on green diet on preschool children's awareness of respect for life, community spirit and considerate behavior (Yu, 2018), and effects of talking using personality-related stories on preschool children's awareness of respect for life and emotional intelligence (Choi, 2016).

\section{Verification of effects of the forest healing program on preschool children's prosocial behavior}

\section{Testing of pretest-posttest effects}

Table 10 shows the pretest-posttest mean and standard deviation of prosocial behavior for each group.

As shown in pretest-posttest changes of Table 10, Test group A showed a great increase in the mean from 3.316 to 4.100 through various forest healing program activities using natural objects, but the mean in Test group B increased from 3.233 to 3.750 and the mean in the control group from 3.216 to 3.533. By subfactor, the mean generally increased in personal emotion regulation, interpersonal relationship formation, and kindergarten adaptability. However, Test group A showed a much greater increase than Test group B and Control group.

\section{Pretest-posttest ANCOVA results of preschool children's prosocial behavior according to the implementation of the} forest healing program

To verify the effects of the forest healing program developed in this study on preschool children's awareness of respect for life and prosocial behavior, we conducted ANCOVA that verifies the differences in posttest scores for each group by using the pretest scores of the Testand control groups as covariance. Table 11 shows the results of pretest-posttest ANCOVA among groups regarding prosocial behavior.

As shown in Table 11, children in the Test groups that participated in the forest healing program using natural objects showed a significant increase overall as a result of testing their prosocial behavior. Significant differences were verified in

Table 10. Pre- and post-test effects of prosocial behavior of children

\begin{tabular}{|c|c|c|c|c|c|}
\hline \multirow{3}{*}{ Factor } & \multirow{2}{*}{ Sub-factor } & \multirow{2}{*}{ Group } & \multirow{2}{*}{$\mathrm{n}$} & Before & After \\
\hline & & & & \multicolumn{2}{|c|}{$\mathrm{M} \pm \mathrm{SD}$} \\
\hline & \multirow{3}{*}{ Ability to regulate personal emotions } & Test group A & 20 & $3.100 \pm .307$ & $3.900 \pm .447$ \\
\hline \multirow{11}{*}{$\begin{array}{l}\text { Prosocial } \\
\text { behavior }\end{array}$} & & Test group B & 20 & $3.150 \pm .366$ & $3.750 \pm .444$ \\
\hline & & Control group & 20 & $3.100 \pm .307$ & $3.350 \pm .489$ \\
\hline & \multirow{3}{*}{ Ability to build interpersonal relationships } & Test group A & 20 & $3.350 \pm .587$ & $4.250 \pm .444$ \\
\hline & & Test group B & 20 & $3.300 \pm .571$ & $3.700 \pm .656$ \\
\hline & & Control group & 20 & $3.250 \pm .550$ & $3.650 \pm .489$ \\
\hline & \multirow{3}{*}{ Ability to adapt to kindergarten } & Test group A & 20 & $3.550 \pm .510$ & $4.150 \pm .670$ \\
\hline & & Test group B & 20 & $3.550 \pm .510$ & $3.800 \pm .523$ \\
\hline & & Control group & 20 & $3.400 \pm .502$ & $3.600 \pm .502$ \\
\hline & \multirow{3}{*}{ Total } & Test group A & 20 & $3.316 \pm .366$ & $4.100 \pm .307$ \\
\hline & & Test group B & 20 & $3.233 \pm .326$ & $3.750 \pm .262$ \\
\hline & & Control group & 20 & $3.216 \pm .329$ & $3.533 \pm .331$ \\
\hline
\end{tabular}


Table 11. Pre- and post-categorical covariance analysis of prosocial behavior of children after forest healing programs

\begin{tabular}{|c|c|c|c|c|c|c|c|}
\hline Factor & Sub-factor & Variable Source & SS & $\mathrm{df}$ & MS & $\mathrm{F}$ & $p$ \\
\hline \multirow{16}{*}{$\begin{array}{l}\text { Prosocial } \\
\text { behavior }\end{array}$} & \multirow{4}{*}{$\begin{array}{l}\text { Ability to regulate } \\
\text { personal emotions }\end{array}$} & Covariance & 1.717 & 1 & 1.717 & & \\
\hline & & Intergroup & 3.154 & 2 & 1.577 & 8.505 & $.001^{\text {** }}$ \\
\hline & & Error & 10.383 & 56 & .185 & & \\
\hline & & Total & 822.000 & 60 & & & \\
\hline & \multirow{4}{*}{$\begin{array}{l}\text { Ability to build } \\
\text { interpersonal } \\
\text { relationships }\end{array}$} & Covariance & 1.245 & 1 & 1.245 & & \\
\hline & & Intergroup & 4.111 & 2 & 2.055 & 7.546 & $.001^{* *}$ \\
\hline & & Error & 15.255 & 56 & .272 & & \\
\hline & & Total & 918.000 & 60 & & & \\
\hline & \multirow{4}{*}{$\begin{array}{l}\text { Ability to adapt to } \\
\text { kindergarten }\end{array}$} & Covariance & 7.861 & 1 & 7.861 & & \\
\hline & & Intergroup & 2.145 & 2 & 1.072 & 5.618 & $.006^{* *}$ \\
\hline & & Error & 10.689 & 56 & .191 & & \\
\hline & & Total & 911.000 & 60 & & & \\
\hline & \multirow{4}{*}{ Total } & Covariance & 1.675 & 1 & 1.675 & 26.653 & \\
\hline & & Intergroup & 2.657 & 2 & 1.329 & 21.139 & $.000^{* *}$ \\
\hline & & Error & 3.519 & 56 & .063 & & \\
\hline & & Total & 872.333 & 60 & & & \\
\hline
\end{tabular}

${ }^{*} p<.05,{ }^{* *} p<.01$

subfactors of prosocial behavior such as ability to regulate personal emotions and ability to build interpersonal relationships. This is consistent with previous studies proving the effects of after-school forest healing program activities on preschool children's prosocial behavior and increase in self-efficacy (Jang and Koo, 2017), proving the effects of cooperative arts and crafts activities on all subfactors of preschool children's prosocial behavior (Kim, 2015), and arguing that there is not much difference between carrying out the Nuri Curriculum activities in the forest and carrying out activities indoors at the early childhood educational institution (Cho, 2014).

These study results are consistent with other studies claiming that preschool children who participated in forest experience activities quickly perceive emotions felt toward themselves and others, and have the ability to regulate their thoughts (Kim, 2008), studies on preschool children's respect for life and prosocial behavior according to ecological experiences (Aan, 2007; E.S. Kim, 2013; Oh, 2017; So, 2016), and studies on the effects of outdoor cooperative play using natural objects on improving preschool children's self-conception and prosocial behavior (Chai, 2016; Lee, 2012), which proved that there are significant differences in subfactors of prosocial behavior. However, there was no statistical significance in the ability to adapt to the kindergarten among the groups in this study.

\section{Conclusion}

This study is to determine the effects of implementing an forest healing program using natural objects on preschool children's awareness of respect for life and prosocial behavior. The following conclusions can be made based on the results of this study.

First, Test group A that carried out forest healing program activities in the forest showed a greater improvement in the awareness of respect for life from the pretest compared to the Control group and Test group B that carried out the program 
in the classroom, and also showed positive effects. Test group A also showed a greater improvement in the subfactors of awareness of respect for life such as perspective on respect for life, knowledge of respect for life, and cooperative behavior with respect for life. Second, Test group A that carried out the program in the forest showed higher prosocial behavior than the Control group and Test group B that carried out the program in the classroom. Test group A also showed a greater improvement in the subfactors of prosocial behavior such as ability to regulate personal emotions, ability to build interpersonal relationships, and ability to adapt to the early childhood educational institution. However, there was a difference in the ability to adapt to the kindergarten among groups. Third, through the sensory factors of the five senses activities in the open space of the forest (smelling, seeing, tasting, touching, and listening to the sounds of the forest), children could enjoy playing with natural objects and showed improvement in their awareness of respect for life. Fourth, enjoying the forest landscape and walking along the trail was effective in recovering stability physically and mentally due to forest healing factors such as physical and chemical factors (sunlight, wind, anion, phytoncide, landscape and topography).

Furthermore, since the forest space provides more freedom for the children than being in class at the educational institution, there was a positive effect on improving respect for life or prosocial behavior as they made new discoveries and observations in the forest.

As examined above, the forest healing program using natural objects showed significant improvement overall in awareness of respect for life and prosocial behavior of Test group A that carried out the program in the forest than Test group B and Control group.

Based on the conclusions of this study, we would like to make a few suggestions.

First, this study examined the effects of forest healing program activities on preschool children's awareness of respect for life and prosocial behavior once a week through 12 sessions. However, their awareness of respect for life and prosocial behavior constantly develop and grow according to their developmental stages. Thus, a long-term systematic research is necessary. Second, since forest healing program activities using the forest provide more freedom than classes in the educational institution, it is necessary to create an environment with all kinds of outdoor play to conveniently use in the institution. There is also a need to develop programs that can be carried out regardless of the weather or season. Third, this study may have limitations in generalizing the results as it was conducted for 1 hour (60 minutes) during the free choice activity period after the morning routine of 5-year-old children. Therefore, follow-up research must be conducted on children of various age groups by also increasing the hours using various research methods. Fourth, this study was conducted on preschool children in general, but it is also necessary to study the differences in preschool children's awareness of respect for life and prosocial behavior according to the forest healing program caused by the different genders of the children.

\section{References}

Aan, H.J. 2007. The study on ecological experience program for infant's respectful recognition of life and pro-social behavior. Master's thesis, Jinju National University, Jinju, Korea.

Baeg, G.H. 2014. The influence of ecology experience activity on nature-friendly attitude and life respect concept of preschoolers. Master's thesis, Kyungnam University, Changwon, Korea.

Chai, S.M. 2016. The effects of outdoor cooperative play activities using natural materials on the self-concept and pro-social behaviors of young children. Mater's thesis, Soong-sil University, Seoul, Korea.

Cho, E.S. 2014. A study on Nuri curriculum in real situation at forest kindergarten. Master's thesis, Seoul National University of Education, Seoul, Korea. 
Choi, N.Y. 2016. The effect of moral story sharing activities using children's story on child's life respect awareness and emotional intelligence. Master's thesis, Dongguk University, Seoul, Korea.

Choi, S.L. 2013. The effect of nature experience in the forest on young children's social competence and self-efficacy. Master's thesis, Korea National Open University, Seoul, Korea.

Gwon, E.H. 2003. The effects of play activities in a nature-friendly outdoor environment on children's self concept and pro-social behavior. Master's thesis, Daegu University, Daegu, Korea.

Hay, D.F. 1984. Social conflict in early children education. In G.J. Whitehurst (Ed.), Annals of Child Development 1, (pp. 1-44). Greenwich, CT: JAI Press.

Hong, E.J. 2003. Educational meaning search of nature environment composition activity. Doctoral dissertation, Chung-Ang University, Seoul, Korea.

Jang, C.S. 2017. Effect of five senses experience in forest on young children's self-efficacy and creativity. Master's thesis, Chungbuk National University, Cheongju, Korea.

Jang, C.S. and C.D. Koo. 2017. Effects of after-school forest healing program activities on infant's pro-social behavior and self-efficacy. Korean J. Environ. Ecol. 31(6):595-605.

Kim, D.O. 2008. Effects of school forest experiential activities on the emotional change of children. Master's thesis, Kyungnam University, Changwon, Korea.

Kim, E.S. 2013. Impact of play in forest on children`s pro-social ability. J. Korea Open Assoc. Early Child. Educ. 18(4):205-229.

Kim, G.S. 2002. A study on the perception of parents and teachers about early childhood education. Master's thesis, Dongguk University, Seoul, Korea.

Kim, H.W. 2015. The effects of cooperative design activities using children's natural products on children's creativity and prosocial behavior. Master's thesis, Kyungin National University of Education, Incheon, Korea.

Kim, K.S. 2013. The influence of education in forest preschool on Infant 's prosocial behavior ability. Master's thesis, Incheon University, Incheon, Korea.

Kwon, G.I. 2011. The affect of child meditation activity utilizing ecology picture book on children's life respecting perception and nature friendly attitude. Master's thesis, Dongguk University, Seoul, Korea.

Lee, H.K. 2012. The effect of cooperative physical expression activities on young children's prosocial behavior. Master's thesis, Korea National University of Education, Seoul, Korea.

Lee, H.O. 2005. Effects of life world project for infant's life respect attitude. Master's thesis, Sookmyung Women's University, Seoul, Korea.

Lee, J.H. 2015. Effects of forest Meditation nature play activities of children were with recognized respect for life and selfregulation. Master's thesis, Dongguk University, Seoul, Korea.

Lee, W.Y. 2008. Parent Education for Infants and Young Children. Seoul, Korea: Book Cafe.

Lim, J.T. 2007. Introduction to Early Childhood Education. Seoul, Korea: Yangsewon.

Ministry of Education and Science Technology. 2012. 3 5 years-old Nuri process manual. Dajeon, Korea: Author.

Ministry of Education and Science Technology. 2015. 3 5 year-old Nuri process manual. Dajeon, Korea: Author.

Moore, R.C. 2000. Children immersed in Nature. Paper presented at the 8th International Conference on Environment and Safety for Children by Samsung Welfare Foundation. Seoul, Korea.

Nam, H.C. 2004. I go to the forest every day. Seoul. Korea: Cheonglim publishing.

Oh, N.L. 2017. Influence of ecological experiences in the forest on infant's nature-friendly attitude and awareness by ecological experiences in the forest. Master's thesis, Kyung Hee University, Seoul, Korea.

Oh, S.Y. 2010. Impact of literary activities in the forest on the verbal expressiveness of preschoolers: the case of a forest kindergarten attached to University of Incheon. Master's thesis, Incheon University, Incheon, Korea.

Seo, Y.M. 2008. The effects of mathematical inquiry activity based on forest experience on the children's mathematical problem solving ability and attitude toward mathematics. Master's thesis, Chungang University, Seoul, Korea. 
Shin, W.S. 2007. Health trip to the forest. Seoul, Korea: Jiseongsa.

So, D.W. 2016. The effects of the small group picture storybook making activity on children's pro-social behavior. Master's thesis, Korea National University of Education, Seoul, Korea.

Wilson, R.A. 1995. Nature and young children: A natural connection. Young Child. 50(6):4-11.

Yu, H.L. 2018. The effect of character education activities based on green diet on children's perception of life respect, community spirit and caring behavior. Doctoral dissertation, Wonkwang University, Iksan, Korea. 
